\title{
ADVERTISING ACTIVITY OF HALAL RESTAURANT BUSINESS: THE EXAMPLE OF KAZAN
}

\author{
Sergey Rychkov \\ Kazan Innovative University named after V. G. Timiryasov (IEML), Russia \\ e-mail:rychkovkazan@rambler.ru
}

\begin{abstract}
The article, based on the analysis of the Internet sites giving information on halal restaurant services in Kazan, statistical and other sources, presents an estimation of their advertising. The comparative analysis is carried out of cafes' and restaurants' advertisements in seven Russian cities, the conclusion is made about the leading role of Kazan in the studied segment of the growing halal market by its saturation with this kind of services.

Based on the estimation of certification agencies' activity for compliance with the "Halal" standard, the general and specific features of certification systems are included of the regions where the studied cities are located. The specific features include different extent of the state participation in the certification procedure.

Recommendations have been elaborated. The administrators of the Internet sites giving information on halal cafes and restaurants should maximally control its reliability. Efforts should be made to certify producers for compliance of their services with the "Halal" standard, and to advertise the certified restaurant business entities. It is appropriate to disseminate the experience of the Republic of Tatarstan in joint certification by a specialised division of a centralised Muslim organisation and an authorised state agency.
\end{abstract}

Keywords: advertisement, cafes and restaurants, certification, halal, Halal standard, Kazan 


\section{Introduction}

A lot has been written about the significant growth rate of Islamic economy. Our research is focused on the sphere of restaurant business, in which the Shariah norms play an increasing role. Researchers not only mark the increase of absolute and relative numbers of Muslims in the world, but also emphasise the culturological and hygienic components of such comprehensive and multi-sided phenomenon as the "halal" principle - eating the "lawful", permissible food, corresponding to the Islamic norms (Syed Shah 2011; Khalek 2014; Mohani \& Hashanah et al. 2013; Shahidan \& Othman 2006; Bondarenko \& Dzotcoeva 2016, etc.).

"Halal" marking implies that the product does not contain any components forbidden for the Muslims (pork, blood, etc.) and is a pure product. In short, halal is an ecologically pure product manufactured in accordance with the Islamic norms. Halal food can be eaten by people of any nationality and faith.

The diversity of the religious behaviour of the believers is determined by many factors. Our research reveals the role of religious determinant in gastronomical, or nutritional behaviour. This is a comprehensive definition, including both the external components (the role of religion in the society, the state ethno-confessional policy, presence and activity of various theological schools, the activity of other institutions, including market ones) and the internal ones (a person's attitude towards religion, the level of their religious knowledge and education). These components are multidirectional. For example, the functioning of several mazhabs in Islam implies multifaceted behaviour of the believers of different ethnoses. On the contrary, the efforts of the state are usually aimed at reducing the number of subjects influencing the believers' behaviour.

A significant role in market institutions' activity is played by advertisement. Advertisement pursues the commercial, marketing and communicative goals (Kolyshkina \& Markova et al. 2017: 23).

The summarised list of criteria of international halal systems refers to the requirements for company profiles, employees, premises, equipment, raw materials, suppliers, logistics, packing and marking, documentation and processes.

The research of certification issues is geographically widely spread, but prevails in the South-Eastern Asia, in particular, in Malaysia (Shahidan \& Othman 2006; Khalek 2014). Certification issues became topical in that region at 
the end of the 1970s-1990s; this means that Russia in general and the Republic of Tatarstan in particular, where the standard was adopted in 2002 (Orlova \& Zinov'eva 2015: 40), are in line with the countries most advanced in respect of certification. Researchers emphasise the significance of certification for those countries and regions where the Muslim population is not a predominant majority, as the product and ingredient suppliers may not be Muslims and may not therefore observe the halal rules.

Different regions of the world have their own certification systems, differing both by the number of criteria and by some fundamental approaches. Thus, most certifying bodies do not require an enterprise to belong to Muslims; some insist on certifying all sales outlets of a company, as well as its suppliers (Abd Latif \& Mohamed et al. 2014).

Our research objective is to elaborate recommendations to those who influence the halal services consumers in the sphere of restaurant business in Kazan aimed at improving their advertising activity. Our tasks were: to carry out comparative analysis of cafés and restaurants advertisements in Kazan and six other Russian cities; to estimate the compliance of restaurant certification procedure with the halal standard.

The following sources were used: databases of state statistics, Internet sites containing information on halal services of cafés and restaurants and various aspects of halal industry, scientific publications on the topic. The research methods were comparative analysis and synthesis, traditional and content analysis of documents; summarising of the quantitative data in an analytical datasheet.

The scientific novelty lies in the fact that this research is the first attempt to interpret the advertising activity of the Russian restaurants rendering halal services to their customers. The practical significance of the research is the recommendations in the sphere of research offered to the halal cafés and restaurants, as well as to the bodies certifying their business. 


\section{Comparative Characteristics of the Advertisement Sphere of Halal Market of Cafés' and Restaurants' Services}

According to the results of All-Russia census of 2010, the share of ethnoses traditionally professing Islam in selected cities was the following: in Kazan 47.6\% - Tatars (Nacional'nyj sostavTatarstan 2012: 3); in Ufa - 45.4\% - Tatars and Bashkirs (Itogi Bashkortostan 2012: 12); in Moscow - 2.46\% - Tatars, Azerbaijanis, Uzbeks, Tajiks, Chechens (Naselenie 2012); in Saint Petersburg 1.6\% - Tatars, Uzbeks, Azerbaijanis (Osnovnye itogiPeterburga 2014: 27); in Ulyanovsk - 11.44\% - Tatars and Azerbaijanis (Svodnye itogi 2014: 183); in Groznyi (Osnovnye itogi 2017: 168) and Makhachkala (O nekotoryh itogah 2014: 20), according to the regional statistics - over 95\%. These statistical data cannot be used for accurate measurements of the halal services market in these cities, because the factors of migration, tourism and way of life should be taken into account.

In March 2017, the author performed a comparative analysis of the texts of cafes' and restaurants' advertisements in Kazan, Moscow and Ufa. The research objective was to give recommendations to the restaurant business enterprises aimed at improving the communication policy. The tasks included: to construct a sample of advertisers; to reveal the presence of absence of mentions about the compliance of the advertised food with the Islamic canons and/or the conceptions of healthy food; to compare the situation in Kazan, Moscow and Ufa by the above characteristic; and to formulate conclusions and recommendations. The sources of information were the Internet sites containing the summarised data on cafes' and restaurants' services in the above cities, including those rendering halal services; first source is the HalalGuide website, which integrates information about halal services in the Russian local markets (Kasimov 2018). Information was collected using the method of content analysis. The sample comprised cafes and restaurants positioning themselves as offering halal food and the cuisines of Muslim ethnoses (Tatar, Bashkir, Azerbaijani, Uzbek, Tajik, as well as Caucasian or Oriental cuisine): 30 enterprises in Kazan, 27 in Moscow and Ufa each. 
The HalalGuide website classifies the represented cafes and restaurants into three zones: "green" - the business entity observes the halal standard and is certified by one of the authorised bodies; "yellow" - the business entity observes the halal standard but is not certified by any authorised body, and "red" - the enterprise serves alcohol, which is one of the gross violations of the Shariah norms.

In Moscow, the overwhelming majority of the researched cafes and restaurants $(81.5 \%)$ use the regional component in Internet advertisement. In most cases this is information about halal food, two enterprises (7.4\%) offer arranging celebrations in compliance with the Muslim traditions - hatm, nikah, alcohol-free weddings, iftar.

In Kazan, the share of the researched cafes and restaurants using the religious motif in advertisement is $30 \%$; these are mainly the cafes and restaurants offering Caucasian and Central Asian cuisine alongside with the Tatar one. In Ufa, the share of such catering enterprises is $48.1 \%$.

We found information (two enterprises in Ufa) about using the healthy food traditions in cooking (natural, diet products, alcohol-free celebrations). In all cases (eleven in Moscow, six in Kazan, three in Ufa), such texts are mainly characteristic of the advertisement of those enterprises which use the religious component.

A typical example of a text with the religious component is the following advertisement of a certified café "Itle" in Kazan: "We stick to strict Halal standards at all stages of production: from selecting suppliers and butchering to grilling meat and the overall atmosphere of the place"(Pervyj v Rossii n/a).

We can conclude that some representatives of restaurant business include in their Internet advertisements information on compliance of their services with the Islamic canons together with the statements that their food corresponds to the norms of healthy nutrition. In Moscow this combination is rather common; in Kazan and Ufa it is less common. Supposedly, the reasons for that are: higher level of marketing communications in the capital; in Moscow the level of marketing is higher; the Tatar and other Muslim diasporas in Moscow are more sensitive to observing the Islamic canons in everyday life.

We recommend the representatives of restaurant business, positioning themselves in the markets of national cuisines of the Muslim peoples, to actively use information on compliance of their services with the Islamic canons in 
advertising their services. This should be done on conditions that they observe these canons in their production. The inclinations for healthy nutrition among the consumers of catering services are increasing; due to that, the emphasis on the halal products' compliance with the norms of healthy lifestyle will enhance the competitiveness of such cafes and restaurants.

The author shares the opinion of a Saudi Arabian tourist who visited Kazan in March 2018, who, leaving positive comments about the city's preparedness for rendering catering services corresponding to "Halal" standard, also recommended to arrange navigation relevant to their location, with guideboards and signs (Ahmad Halaf Ar-Rashidi 2018).

In February-March 2018, we performed the research of advertising activity of restaurant business entities. The research objective was to formulate recommendations for the HalalGuide website administration and the owners of cafes and restaurants, who place their advertising information in that website; the recommendations were to improve the halal services promotion in the local markets of Kazan, Ufa, Moscow, Saint Petersburg, Ulyanovsk, Groznyi, and Makhachkala. The geographical frameworks of the research were broadened in order to reveal the trends in advertising of the halal sector of restaurant business in Russia. To compare with Kazan, we have selected two cities with a rapidly growing share of Muslim population (Moscow and Saint Petersburg); two cities - centre of the Russian Federation subjects with mostly Muslim population (Makhachkala - the capital city of the Republic of Dagestan, Russia, and Groznyi, the capital city of the Chechen Republic, Russia); Ufa (Öfö) - the capital city of the Republic of Bashkortostan with a share of Muslim population, close to that in Kazan, the centre of a region neighbouring the Republic of Tatarstan; Ulyanovsk - the centre of a region neighbouring the Republic of Tatarstan, a city with a significant share of Muslim population. The source of information was the website HalalGuide (Table 1). It is important to note that anyone may add a halal enterprise to the website. The website administration also states that they are not responsible for the reliability of information placed on the website. This means that the website administration does not check the information of the presence of certificate for the offered food compliance with the halal standard, as well as other information. 
Table 1. Advertisement of the halal sector enterprises of restaurant business in seven Russian cities.

\begin{tabular}{|l|l|l|l|l|l|}
\hline City & $\begin{array}{l}\text { Number } \\
\text { of cafes } \\
\text { and res- } \\
\text { taurants } \\
\text { on the } \\
\text { website, } \\
\text { units }\end{array}$ & $\begin{array}{l}\text { By 100 } \\
\text { thousand } \\
\text { people }\end{array}$ & $\begin{array}{l}\text { Number of } \\
\text { cafes and } \\
\text { restau- } \\
\text { rants in } \\
\text { the "green } \\
\text { zone", units }\end{array}$ & $\begin{array}{l}\text { Number } \\
\text { of cafes } \\
\text { and res- } \\
\text { taurants in } \\
\text { the "green } \\
\text { and yellow } \\
\text { zones", units }\end{array}$ & $\begin{array}{l}\text { Number of } \\
\text { cafes and } \\
\text { restau- } \\
\text { rants in } \\
\text { the "green } \\
\text { and yellow } \\
\text { zones", \% }\end{array}$ \\
\hline Kazan & 144 & 12.59 & 23 & 138 & 95.8 \\
\hline Moscow & 134 & 1.16 & 9 & 105 & 78.4 \\
\hline Ufa & 36 & 3.39 & 2 & 35 & 97.2 \\
\hline $\begin{array}{l}\text { Saint } \\
\text { Petersburg }\end{array}$ & 25 & 0.51 & 2 & 18 & 72.0 \\
\hline Ulyanovsk & 5 & 0.78 & 1 & 5 & 100 \\
\hline Groznyi & 13 & 4.79 & 2 & 13 & 100 \\
\hline Makhachkala & 57 & 8.18 & 12 & 57 & 100 \\
\hline Total & 414 & & 50 & 371 & 89.6 \\
\hline
\end{tabular}

Source: HalalGuide. https://halalguide.me/.

The indicator "Number of cafes and restaurants offering halal services, by 100 thousand people of the city population" is introduced to determine the saturation of the market with these services. We do not determine the saturation of the cities in regard to the Muslim population due to the following three reasons. First, there are no statistics concerning the citizens' confessions; these estimations are made in terms of the ethnic composition of the population, and they are very approximate. Second, the range of services of cafes and restaurants is largely determined by the volume and character of incoming tourism. Third, we are convinced that the halal services in cafes and restaurants are not intended solely for the Muslims, but for everyone who is oriented towards healthy eating. This is the main positioning factor of advertisement of halal cafes and restaurants. 
The highest saturation of the supply is observed in Kazan. The following positions belong to, in the descending order, Makhachkala, Groznyi, Ufa, Moscow, Ulyanovsk, and Saint Petersburg. Supposedly, the leading position of Kazan is related, first of all, to the active participation in the tourist market which is characteristic of the regional and municipal authorities and business community. In Kazan, the volume of incoming tourism in 2017 was 2.7 million people, which is $10 \%$ more than in 2016. The number of foreign tourists was 185.000 people (Analitika 2018). About one third of comments regarding the services of "green zone" cafes and restaurants were from the tourists who came from other Russian cities. Advertisements of the halal restaurant business entities play an important role in achieving such results; it is an additional factor of gastronomical environment influencing the behaviour of the city population.

Absolute majority of restaurant business entities stick to the main halal principles in this sphere of activity - not offering alcohol, which constitutes the main share of potential income and profit (89.6\% of enterprises). According to our preliminary observations, this number is constantly growing. At the same time, the share of certified enterprises is only $12.1 \%$.

\section{The Procedure of Restaurant Business Enterprises' Certification for Compliance with the Halal Standard}

There is no centralised system of product certification for compliance with the halal standard in Russia. The author gives a brief review of the system of cafes' and restaurants' services certification, with the focus on characteristic of the certification procedure carried out by the Committee on Halal Standard of the centralised religious institution - Spiritual Directorate of the Muslims of the Tatarstan (hereinafter - the Committee) (Procedura sertifikacii). The choice of this priority is due to the author's location as well as to the leading position of Kazan in offering halal services by the cafes and restaurants, which was shown in the previous section.

The Committee was founded in 2005; in four years, together with the Republic Certification Methodological Centre "Test-Tatarstan" (hereinafter the Centre) Close Corporation performing certification on behalf of the state, it elaborated "General requirements on production and marketing of 'halal' products". 
The certificate confirms:

- using the raw materials and processing methods that do not entail harm to humans and the environment,

- rejecting the use of products that include genetically modified and forbidden ingredients,

- ensuring the observance of sanitary-hygienic requirements for producing and storing the products and raw materials,

- ensuring the presence of reliable information on the product label (Podrobnee ob industrii). Thus, the certification authority emphasises, first and foremost, the compliance of the certified service with the norms of healthy nutrition, drawing it beyond the frameworks of any confession. The Committee is involved not only in certification, but also educational-enlightenment, marketing, organisational, and coordination activity.

The voluntary certification procedure carried out by the Committee together with the Centre consists of ten stages. The procedure implies the obligatory visit of the Committee expert and a representative of the Centre to the production site and filling in the testing certificate. The final result is the acquisition of the state certificate of compliance with the "Halal" standard at the Centre (Procedura sertifikacii). Acquisition of such certificate indicates the compliance of the rendered service with both the Shariah norms and the requirements of the Russian legislation. This is the only example of parallel confessional and state certification.

As of April 2018, five restaurant business entities were certified jointly by the Committee and the Centre (taken into account only the enterprises which had a confirmed or prolonged certificate as of the moment of access). This means that the majority of certified sales outlets were certified in other regions (Reestr sertificirovannyh predprijatij). In general, as of 30 March 2018, the register listed 118 enterprises and businesspersons, 61 of them from Tatarstan, 47 from other regions. In Russia there are over 500 certified subjects of this business (Novosti).

In Moscow, there are two certification agencies: "Tsentr Halal Nadzor" Centre for certification and standardisation of the Spiritual Directorate of the Muslims of Moscow and Central region of Russia - there are no cafes and restaurants in the register (Reestr sertificirovannyh organizacij) and International "Halal" Centre for certification and standardisation under the Russia Muftis Council - one acting certificate (Magaziny i restorany). 
In Ulyanovsk Region, certification is carried out by the non-profit organisation for promoting the halal standard observance "Halal 73" (Sertifikacija 2016), in Saint Petersburg, Ufa (Bashkortostan), Dagestan Republic - the "Halal North-West" Centre for certification and standardisation, founded under the Spiritual Directorate of the Muslims of Saint Petersburg and the North-West region of Russia (Centr Haljal'), and "Sertifikat RB" Open Corporation (Sertifikacija Haljal 2018).

In Chechen Republic, the voluntary certification system was elaborated in the middle of 2016 by an inter-departmental commission organised by the order of regional government; the system was titled "Halal - Chechen Republic". Its peculiar feature is that the service is free of charge (Sistema).

Comparing the information of certification agencies' registers and the HalalGuide website shows that the website poorly traces the validity of the certificates issued to cafes and restaurants, which leads to reduction of reliability of the data placed in it. It should be noted, however, that the register pages are either absent, or left unfilled in the majority of certification authorities' websites.

In Russia there is a well-developed system of voluntary certification of producers for compliance of their products with the Halal standard, which extends its power to the restaurant business, too. In some regions, this system is more or less centralised (Tatarstan, Chechnya); the reason for this is the joint activity of spiritual Muslim organisations and the state. However, more often the Russian subjects have several officially registered certification agencies. Any certification agency renders its services not only within its region but at the inter-regional level too.

\section{Conclusion}

Due to a number of external factors, favourable for halal segment development in the sphere of cafes' and restaurants' services, Kazan, the capital city of Tatarstan, is leading among the Russian cities in this segment. The author recommends the administrators of websites generating information about this business to take responsibility for reliability of this information by introducing checking procedures. The author recommends the owners and managers of sales outlets, when publishing information on the Internet about the compliance of their services to halal standard, to emphasise the principles and norms of healthy lifestyle and hygienic nutrition inherent in halal food and services. 
It is necessary to promote both the certification of producers and products in compliance with halal standards and advertising the certified services of restaurant business subjects. This is necessary from the viewpoint of propagating the healthy lifestyle, hygienic and ecological norms in nutrition, and the rules of consumerism. Besides, certification and its advertising facilitate sales in the growing market segment, especially in tourist centres with increasing tourist flow from Muslim countries, including cities such as Kazan. The author proposes that the Tatarstan experience in coordinating the efforts of Muslim organisations and the state in the sphere of certification is disseminated in those Russian regions and foreign countries where the interested representatives of confessions, authorities and business would be able to draw the necessary analogies and come to certain agreements in the interest of consumers.

\section{Acknowledgements}

The article is prepared with the financial support of the Russian Foundation for Basic Research, project No. 16-01-00285-OGN "Religious determinants in a culture of food (on example of the Tatars and the Tajiks of Kazan)".

\section{References}

Abd Latif, Ismail \& Mohamed, Zainalabidin \& Juwaidah, Sharifuddin \& Amin, Mahir Abdullah \& Mohd Mansor, Ismail 2014. A Comparative Analysis of Global Halal Certification Requirements. Journal of Food Products Marketing, No. 20, pp. 85-101. DOI: doi.org/10.1080/10454446.2014.921869.

Ahmad Halaf Ar-Rashidi 2018. Kazan' horosho podgotovlena dlja turistov iz musul'manskih stran [Kazan is Wellprepared for Tourists from Muslim Countries]. Novosti, 16.03. Available at https://www.kzn.ru/meriya/ispolnitelnyy-komitet/mbukomitet-sodeystviya-razvitiyu-turizma-g-kazani/novosti/akhmad-khalaf-arrashidi-kazan-khorosho-podgotovlena-dlya-turistov-iz-musulmanskikh-stran/, last accessed on 17.04.2018.

Analitika [Analytics] 2018. V 2017 godu Kazan' posetili 2,7 milliona turistov. Realnoe vremja, 29.01. Available at https://realnoevremya.ru/news/88041-v-2017-godukazan-posetili-27-milliona-turistov, last accessed on 07.04.2018.

Bondarenko, Viktorija \& Dzotcoeva, Kristina 2016. Tendencii razvitija industrii haljal' $v$ SShA i rjade evropejskih stran [Trends in the Development of Halal Industry 
in the USA and several European countries]. Ekonomika i predprinimatel'stvo, No. 3-1 (68-1), pp. 48-51.

Centr Haljal' Severo-Zapad 2017 [Center Halal North-West]. Avialable at https://dumspb.ru/centr-xalyal-severo-zapad, last accessed on 05.04.2018.

Itogi Bashkortostan 2012 = ItogiVserossijskoj perepisi naselenija po Respublike Bashkortostan, po dannym Vserossijskoj perepisi naselenija 2010 goda. Ufa: Bashkortostanstat [Results of the All-Russian Population Census in the Republic of Bashkortostan]. Available at http://bashstat.gks.ru/wps/wcm/connect/ rosstat_ts/bashstat/ru/census_and_researching/census/national_census_2010/ score_2010/, last accessed on 05.03.2018.

Kasimov, Ayrat 2018. O proekte [About the Project]. Halal Guide. Available at https:// halalguide.me/about, last accessed on 05.03. 2018.

Khalek, Aiedah Abdul 2014. Young Consumers' Attitude towards Halal Food Outlets and JAKIM's Halal Certification in Malaysia. Procedia - Social and Behavioral Science, Science Direct, Vol. 121, pp. 26-34. DOI: https://doi.org/10.1016/j. sbspro.2014.01.1105.

Kolyshkina, Tat'jana \& Markova, Elena \& Shustina, Irina 2017. Reklamnyj obraz: tehnologii vozdejstvija na massovoe soznanie [Advertising Image: Technologies of Influence on Mass Consciousness]. Jaroslavl': RIO YaGPU.

Mohani, Abdul \& Hashanah, Ismail \& Mazlina, Mustapha \& Hadri, Kusuma 2013. Indonesian small medium enterprises (SMEs) and perceptions on Halal food certification. African Journal of Business Management, Vol. 7 (16), pp. 1492-1500.

Nacional'nyj sostav Tatarstan 2012 = Nacional'nyj sostav naselenija Respubliki Tatarstan [National Composition of the Population of the Republic of Tatarstan]. Territorialnyi organ Federalnoi sluzhby gosudarstvennoi statistiki po Respublike Tatarstan, 10.07. Available at http://tatstat.gks.ru/wps/wcm/connect/rosstat_ts/ tatstat/ru/census_and_researching/census/national_census_2010/score_2010/, last accessed on 05.03.2018.

Naselenie 2012 = Naselenie naibolee mnogochislennyh nacional'nostej po vozrastnymgruppam i istochnikam sredstv sushchestvovanija 2012 [Population of the most Numerous Nationalities by Age Groups and Sources of Means of Subsistence]. Territorialnyi organ Federalnoi sluzhby gosudarstvennoi statistiki po gorodu Moskvy. Available at http://moscow.gks.ru/wps/wcm/connect/ rosstat_ts/moscow/ru/census_and_researching/census/national_census_2010/, last accessed on 05.03.2018.

Novosti Haljal' industrii [Halal Industry News]. Committee on Standard Halal CRO Dum $R T$. Available at http://halalrt.com/newslist?i=4669, last accessed on 05.04.2018. 
O nekotoryh itogah $2014=$ O nekotoryh itogah Vserossijskoj perepisi naselenija 2010 goda v Respublike Dagestan 2014 [About Some Results of the All-Russian Population Census of 2010 in the Republic of Dagestan]. Territorialnyi organ Federalnoi sluzhby gosudarstvennoi statistiki poRespublike Dagestan. Available at http://dagstat.gks.ru/wps/wcm/connect/rosstat_ts/dagstat/ru/census_and_ researching/census/national_census_2010/, last accessed on 05.03.2018.

Orlova, Ksenija \& Zinov'eva, Al'fija 2015. Sovremennoe sostojanie i perspektivy rynka obshhestvennogo pitanija vg. Kazan' [Current State and Prospects of the Catering Market in Kazan]. Ekologicheskij konsalting, No. 3 (59), pp. 38-42.

Osnovnye itogi Peterburga 2014 = Osnovnye itogi Vserossijskoj perepisi naselenija 2010 goda na territorii Sankt-Peterburga 2014 [The Main Results of the All-Russian Population Census of 2010 in the Territory of Sankt-Peterburg]. Territorialnyi organ Federalnoi sluzhby gosudarstvennoi statistiki pog. Sankt-Peterburgu i Leningradskoi oblasti. Available at http://petrostat.gks.ru/wps/wcm/connect/ rosstat_ts/petrostat/ru/census_and_researching/census/national_census_2010/ score_2010/, last accessed on 05.03.2018.

Osnovnye itogi 2017 = Osnovnye itogi Vserossijskoj perepisi naselenija 2010 goda po sub'ektam Severo-Kavkazskogo federal'nogo okruga 2017 [The Main Results of the All-Russian Population Census of 2010 for the Subjects of the North Caucasus Federal District]. Territorialnyi organ Federalnoi sluzhby gosudarstvennoi statistiki po Chechenskoi Respublike. Available at http://chechenstat.gks.ru/ wps/wcm/connect/rosstat_ts/chechenstat/ru/census_and_researching/census/ national_census_2010/, last accessed on 05.03.2018.

Pervyi v Rosii n/a = Pervyj v Rossii haljal'nyj stejk-haus "Itle" [The First Halal Steak House in Russia]. HalalGuide. Avialable at https://halalguide.me/kazan/cafe/ myasnaya- kulinariya-itle, last accessed on 14.03.2018.

Podrobnee ob industrii haljal' [More Information on Halal Industry]. Committee on Standard Halal CRO Dum RT. Avialable at http://halalrt.com/newslist?i=2675, last accessed on 07.04.2018.

Procedura sertifikacii predprijatija v komitete Haljal' [The Procedure for the Certification of the Company in the Halal Committee]. Committee on Standard Halal CRO Dum RT. Avialable at http://halalrt.com/sertification, last accessed on 07.04.2018.

Reestr sertificirovannyh predprijatij - Reestr haljal' predprijatij [Register of Certified Enterprises - Register of Halal Enterprises]. Committee on Standard Halal CRO Dum RT. Avialable at http://halalrt.com/reestr\#kantin, last accessed on 05.04.2018. 
Sertifikacija 2016 [Certification]. Nekommercheskoe partnerstvo sodejstvija sobljudeniju standarta produkcii "Haljal' 73". Avialable at http://halal73.ru/\#top_reasons, last accessed on 05.04.2018.

Sertifikacija Haljal' 2018 = Sertifikacija Haljal' s polucheniem haljal'nyh sertifikatov 2018 [Halal certification with halal certificates]. Sertifikat' RB. Available at https:// www.sertrb.ru/halal/,last accessed on 05.04.2018.

Shahidan, Shafie \& Othman, Md Nor 2006. Halal Certification: an international marketing issues and challenges. Available at http://halalrc.org/images/Research\%20 Material/Report/Halal\%20Certification\%20an\%20international\%20 marketing\%20issues\%20and\%20challenges.pdf, last accessed on 04.03.2018.

Sistema dobrovol'noj sertifikacii "Haljal' - Chechenskaja Respublika" vydaet svidetel'stva proizvoditeljam produkcii [The Voluntary Certification System "Halal-Chechen Republic" issues certificates to the producers of products]. Informacionnoe agenstvo Groznyi inform. Available at http://www.grozny-inform.ru/news/ society/91794/, last accessed on 05.04.2018.

Svodnye itogi Vserossijskoj perepisi naselenija 2010 goda po Ul'janovskoj oblasti 2014 [Summary results of the All-Russian Population Census of 2010 for the Ulyanovsk Region]. Territorialnyi organ Federalnoi sluzhby gosudarstvennoi statistiki po Ulyanovskoi oblasti. Available at:http://uln.gks.ru/wps/wcm/connect/rosstat_ts/ uln/ru/census_and_researching/census/national_census_2010/score_2010/, last accessed on 05.03.2018.

Syed Shah, Alam \& Nazura Mohamed Sayuti 2011. Applying the Theory of Planned Behavior (TPB) in halal food purchasing. International Journal of Commerce and Management, Vol. 21 (1), pp. 8-20. 